\title{
Adverse effects of pine needles on aspects of digestive performance in cattle
}

\author{
JAMES A. PFISTER, DON C. ADAMS, RANDALL D. WIEDMEIER, AND REX G. \\ CATES
}

\begin{abstract}
Authors are with the USDA-ARS Poisonous Plant Res. Lab., 1150 E. 1400 N., Logan, Ut. 84321; Univ. of Nebraska, Lincoln, West Central Research and Extension Center, North Platte 69101; ADVS Dept., Utah State Univ., Logan, Ut. 84322; Dept. of Botany and Range Sci., Brigham Young Univ., Provo, Ut. 84602.
\end{abstract}

\begin{abstract}
Pine needles from ponderosa pine (Pinus ponderosa Lawson) consumed by cows during winter can cause abortions. Our study determined the nutritional impact of pine needles given to steers intraruminally. In Trial 1, 12 steers were given either grass hay alone (CONT), $15 \%$ pine needles (15PN), or $30 \%$ pine needles (30PN) substituted for hay, as fed basis. In Trial 2, a $4 \times 4$ Latin square design was used with 4 steers. Treatments were: (1) controlgrass hay alone (CONT); (2) grass hay plus $454 \mathrm{~g} /$ day of cottonseed meal (CSM); (3) pine needles substituted for $40 \%$ (as fed basis) of the hay (PN); and (4) pine needles (40\%) plus $454 \mathrm{~g} /$ day of CSM (PNCSM). In Trial 1, dry matter intake (DMI), fecal N, and DM digestibility were not affected by either 15PN or 30PN. $N$ intake and $N$ digestibility were reduced $(P<0.07)$ by $30 P N$. Fluid dilution rate (FDR) and fluid outflow rate (FOR) were depressed $(P=0.10)$ by 30PN. Total VFA and ruminal ammonia- $N$ also were depressed by $30 P N$. In Trial 2, the PN treatment adversely affected DMI, N intake, and all digestibility coefficients, and elevated fecal N. FDR, FOR, and turnover time (TOT) were reduced by $40 \%$ PN. Total VFA were increased by $P N$, while ammonia-N concentrations were reduced. Cottenseed meal had few effects on rumen variables, and there were no CSM $\times$ PN interactions. We conclude that pine needles severely affect cattle nutrition, particularly $\mathbf{N}$ intake and digestibility and nuid rate of passage. Cottonseed meal, at 1 $\mathrm{kg} / \mathrm{day}$, does not ameliorate the adverse effects of pine needles. Fifteen to $30 \%$ pine needles in cattle diets appears to be the threshold level for toxic effects on ruminal fermentation.
\end{abstract}

Key Words: Pinus ponderosa, browse, secondary compounds, ruminant nutrition, poisonous plants, toxic effects, phenolics

Ponderosa pine ( Pinus ponderosa Lawson) trees occupy over 17 million ha of rangeland in North America (Gartner et al. 1988). Pregnant cattle may graze large quantities of pine needles (i.e., up to $40 \%$ of their diet) during winter months under free-ranging conditions (Pfister and Adams 1992). Ingestion of needles cause abortion or premature birth, endometritis, and retained placentas in cattle (Lacey et al. 1988, James et al. 1989).

Pine needles contain secondary compounds such as phenolics, terpenes, and tannins (Smith 1964, Hanover 1966). Other studies have shown that these secondary compounds have negative impacts on forage digestibility (Kumar and Singh 1984, Akin 1989), and on rumen microbial populations (Tagari et al. 1965, Akin 1982, Chesson et al. 1982). We recently reported that pine needles negatively impact in vivo and in vitro forage digestibility

\footnotetext{
Supported in part by the Utah Agr. Exp. Sta.; UAES journal paper 4161. The authors wish to thank Lynn Kitchen, Tracy Weber, and James Bair for excellent technical assistance, and Don Sisson for statistical advice. This research was approved by the Animal Care and Use Committee of the USDA-ARS Poisonous Plant Res. Lab.

Manuscript accepted 16 May 1992.
}

(Adams et al. 1992), and are toxic to populations of ruminal microbes in vivo, especially cellulolytic bacteria (Wiedmeier et al. 1992).

Information on the nutritional impacts of pine needles may lead to management alternatives to enhance efficiency of forage use by cattle consuming pine needles. Hence, objectives of our study were to: (1) determine the effects of graded levels of pine needles on forage intake, digestibility, fluid passage rate, and ruminal fermentation, and (2) determine if supplemental protein ameliorated the adverse effects of pine needles. Livestock producers often feed a high-protein supplement to attenuate adverse effects from pine needles.

\section{Materials and Methods}

\section{Carbohydrates, Acids, and Alcohols}

Pine needle tissue was air-dried and ground to pass a 2-mm screen in a Wiley mill. Ground tissue $(500 \mathrm{mg})$ was extracted in 80:20 methanol:water $(20 \mathrm{ml})$. A 9-ml aliquot was blown dry; taken up in pyridine; and $0.5 \mathrm{mg}$ erythritol, the internal standard, was added. Compounds in solution were derivitized with trimethylchlorosilane and hexamethyldisilazane. A 5- $\mu 1$ aliquot of the supernatant fluid was injected into a Hewlett Packard capillary gas chromatograph equipped with a $100 \%$ methyl polysilozane, $25-\mathrm{m}$ column. Nitrogen was the carrier gas at $0.5 \mathrm{ml} / \mathrm{min}$. Injector temperature was $250^{\circ} \mathrm{C}$, detector temperature was $260^{\circ} \mathrm{C}$, and initial temperature was $100^{\circ} \mathrm{C}$ for $1 \mathrm{~min}$. Compounds were identified by co-chromatography using known standards. Data for these compounds, as well as all other compounds, were expressed as $\mathrm{mg} / \mathrm{g}$ dry weight of tissue.

\section{Monomeric Phenolics}

Air-dried, ground plant tissue $(500 \mathrm{mg}$ ) was extracted in $8 \mathrm{ml}$ of $100 \%$ methanol; this was concentrated to $4 \mathrm{ml}$ under $\mathrm{N}$ at $46^{\circ} \mathrm{C}$. Water was added, the extract was washed with $8 \mathrm{ml}$ hexane, and blown dry at $46^{\circ} \mathrm{C}$. Methanol $/ \mathrm{HCL}(0.5 \mathrm{ul})$ was added to the extract; the extract was heated to $100^{\circ} \mathrm{C}$ for $30 \mathrm{~min}$, after which $1-\mathrm{ml}$ of water was added. This mixture was extracted with $1.5 \mathrm{ml}$ ethyl acetate, dried using $\mathrm{Na}_{2} \mathrm{SO}_{4}$, and the internal standard vanillic acid was added $(0.25 \mathrm{mg})$. The ethyl acetate extract was blown dry as above, derivitized in $100 \mu \mathrm{l}$ dimethylformamide and $100 \mu \mathrm{l}$ bis-trifluoracetamide plus $1 \%$ trimethylchlorosilane, and $5 \mu \mathrm{l}$ were injected in a Hewlett Packard capillary gas chromatograph (GC). The GC was equipped with a Hewlett Packard ultra 2, 5\% phenyl $/ 5 \%$ methylsilicone columm, $25 \mathrm{~m}$ in length and ID 0.32 $\mathrm{mm}$. Compounds were identified by co-chromatography using known standards.

\section{Tannins as Analyzed by Astringency}

Because the ecologically important property of tannins has been suggested to be astringency (i.e., protein-complexing activity), 
condensed tannin content was analyzed by the astringency method (Horner et al. 1987). Air-dried, ground plant $(200 \mathrm{mg})$ was extracted in $70 \%$ acetone. Acetone was removed by passing $\mathrm{N}$ over the supernatant fluid at $55^{\circ} \mathrm{C}$, filtered through at $0.45-\mu \mathrm{m}$ nylon filter, and hemoglobin solution used as the reaction protein. The astringency of the tissue was expressed as that relative to the standard quebracho tannin.

\section{Trial 1}

Twelve ruminally cannulated Holstein steers $(285 \pm 27 \mathrm{~kg})$ were allocated randomly to 1 of 3 treatments: controls (CONT) with no pine needles given; $15 \%$ of the basal diet (as fed basis) as pine needles (15PN); and $30 \%$ of the basal diet (as fed basis) as pine needles (30PN). The mature grass hay was a mixture of orchard grass (Dactylis glomerata L.) and brome grass (Bromus spp.). Ad libitum intake of grass hay was determined in a preliminary 10-day period. Feed intake (hay plus needles, as-fed basis) was restricted to $90 \%$ of ad libitum intake during the 14-day trial. Chemical composition of hay and pine needles is given in Table 1. Grass

Table 1. Chemical composition of grass hay and pine needles fed to steers in Trial 1, and grass hay, needles and cottonseed meal fed in Trial 2.

\begin{tabular}{lcc}
\hline & Trial 1 & Trial 2 \\
\hline Grass hay & & \\
\hline Dry matter & 93.6 & 92.6 \\
Ash & 9.5 & 9.5 \\
Crude protein & 7.5 & 8.0 \\
Acid detergent fiber & 38.5 & 36.3 \\
Pine needles & & \\
Dry matter & 93.4 & \\
Ash & 2.2 & 92.2 \\
Crude protein & 5.3 & 2.2 \\
Acid detergent fiber & 39.1 & 5.9 \\
Cottonseed meal & & 42.1 \\
Dry matter & & \\
Ash & & 9.8 \\
Crude protein & & 6.2 \\
Acid detergent fiber & & 16.7 \\
\hline
\end{tabular}

"Dry-matter basis.

hay was chopped through a 50-mm screen, and fed twice daily in equal portions at 0800 and 1500 . Steers were fed in individual locking stanchions. Orts were weighed daily at 1000 and 1700 . Pine needles were collected green from trees during winter in central Montana and air-dried at $25^{\circ} \mathrm{C}$. Dried pine needles were chopped through a $50-\mathrm{mm}$ screen and given intraruminally daily at 0830 for 14 days. Because we were interested in potential ruminal adaptation, no needles were fed during the preliminary period.

Feed and ort samples were collected during days 8 to 13 and 9 to 14 , respectively. Pine needle samples were collected daily, composited, and stored frozen at $-20^{\circ} \mathrm{C}$ in plastic bags. Total fecal collections were made by fecal bags; bags were emptied daily, and feces weighed, mixed, and subsampled during days 10 to 14 . Fecal samples were frozen, and later thawed, oven-dried at $40^{\circ} \mathrm{C}$, ground to pass a $1-\mathrm{mm}$ screen before chemical analyses. Feed and fecal samples were analyzed for crude protein (CP), dry matter (DM), and ash by standard methods (AOAC 1984), and for acid detergent fiber (ADF; Goering and Van Soest 1970).

Steers were dosed at 0800 on day 13 with $500 \mathrm{ml}$ of cobalt ethylenediaminetetraacetate (Co-EDTA, Uden et al. 1980) containing $1,033 \mathrm{mg}$ of Co to estimate fluid passage rate (FPR), turnover time (TOT), ruminal fluid volume (VOL), and fluid outflow rate (FOR). Ruminal samples $(250 \mathrm{ml})$ were taken from the ventral sac immediately before dosing with Co-EDTA, and at 3,6 , $9,12,15,18,24,30,36$, and 48 hours after dosing; samples were frozen immediately. Later, rumen fluid samples were thawed and strained through 4 layers of cheesecloth, and centrifuged at 10,000 $\times \mathrm{g}$ for $20 \mathrm{~min}$. Supernatant fluid was analyzed for Co concentration by atomic absorption spectrophotometry with an air-plusacetylene flame.

At 0800 and 1200 on days $0,2,6$, and $14,250 \mathrm{ml}$ of ruminal contents were collected from the ventral sac, and $\mathrm{pH}$ determined immediately with a combination electrode. The major portion of these samples was used to quantify microbial populations (Wiedmeier et al. 1992). Subsamples were strained through 4 layers of cheesecloth, acidified by adding $1 \mathrm{ml}$ of $20 \% \mathrm{H}_{2} \mathrm{SO}_{4} / 5 \mathrm{ml}$ of sample, and frozen at $-20^{\circ} \mathrm{C}$. After thawing at room temperature, samples were centrifuged at $10,000 \times \mathrm{g}$ for $10 \mathrm{~min}$, and the supernatant fluid was analyzed for ammonia-N. After a second centrifugation and the addition of 2-ethylbutyric acid as an internal standard, concentrations of volatile fatty acids (VFA) were determined using gas chromatography.

Variables not repeated in time were analyzed as a completely random design, with 4 animals per treatment. Orthogonal polynomials were used to test for linear and quadratic effects for apparent digestibility coefficients [DM, organic matter (OM), ADF, CP], digestible DM intake, FPR, TOT, VOL, and FOR. A repeated measures analysis of variance (SAS 1987) and orthogonal polynomials were used to analyze ruminal $\mathrm{pH}$, ammonia- $\mathrm{N}$, and VFA data. All data met the Huynh-Feldt condition required for univariate repeated measures analysis (SAS 1987).

\section{Trial 2}

Four ruminally cannulated Holstein steers (avg. wt. $=364 \mathrm{~kg}$ ) were used in a $4 \times 4$ Latin square design with 4 periods of 12 days each and 4 diets: (1) grass hay alone (CONT); (2) grass hay plus 454 g cottonseed meal/day (CSM); (3) grass hay with pine needles substituted for $40 \%$ of the hay (PN, as-fed basis); and (4) grass hay plus $454 \mathrm{~g} \mathrm{CSM} /$ day and $40 \%$ pine needles (CSMPN). Chemical composition of the hay, CSM, and pine needles is shown in Table 1. Steers were placed in metabolism stalls for a 14-day adaptation period, with ad libitum intake determined for the grass hay during the last 7 days. Steers were removed from the stalls for 7 days then returned for the first trial. Trial periods were 12 days, after which steers were placed together in a common pen and fed alfalfa hay for 14 days, and grass hay for 4 days before beginning another trial period. This procedure was followed to eliminate carryover effects from one trial period to the next.

Hay was fed once daily at 0800 at $90 \%$ of ad libitum intake, and when appropriate, CSM was added to hay. Pine needles were substituted for $40 \%$ of the hay (air-dry basis) and dosed intraruminally at 0815 . Hay and pine needles were chopped through a 50-mm screen, but pine needles were chopped just before each trial period. Orts were weighed each morning.

A pine needle sample was collected daily and frozen. Feed and ort samples were collected from days 6 to 11 and 7 to 12 , respectively. Total fecal collections were made from days 8 to 12 . Feed, orts, fecal, and pine needle samples were stored and analyzed as in Trial 1.

Fluid passage rate was estimated using Co-EDTA as in Trial 1. On day 10 , a $500 \mathrm{ml}$ dose of Co-EDTA was given at 0800 hours; doses contained $1,055,969,1,042$, and $1,101 \mathrm{mg}$ Co for Periods 1 to 4 , respectively. Ruminal samples for Co analysis were collected as in Trial 1.

Ruminal samples also were taken on days $0,2,4,8$, and 12 at 0810 hours, and pH determined as described previously. Subsamples were strained through cheesecloth and prepared and analyzed as noted previously for ruminal ammonia-N and VFA.

Data were analyzed as a $4 \times 4$ Latin square; some variables were 
examined over time, which necessitated use of a repeated measures analysis of variance (SAS 1987). Orthogonal contrasts appropriate for a $2 \times 2$ factorial treatment design were used to compare pine needle effects, CSM effects, and the pine needle $\times$ CSM interaction. Unless otherwise noted, the observed significance level for the F-tests was $\boldsymbol{P}<0.05$.

\section{Results}

\section{Pine Needle Chemistry}

Pine needles contained various kinds and amounts of carbohydrates, organic acids, and an alcohol, inositol (Table 2). Secondary

Table 2. Carbohydrates, acids, and an alcohol in pine needle tissue from central Montana".

\begin{tabular}{lrc}
\hline \hline $\begin{array}{l}\text { Class of compound/ } \\
\text { chemical }\end{array}$ & Trial 1 & Trial 2 \\
\hline Carbohydrate & & \\
$\quad$ Fructose & 5.9 & 3.8 \\
Galactose & 24.5 & 9.3 \\
Glucose & 8.4 & 5.2 \\
Mannose & 0.7 & 0.4 \\
Sucrose & 16.9 & 3.7 \\
Acids & & \\
$\quad$ Shikimic acic & 20.4 & 9.1 \\
Citric acid & 4.7 & 4.3 \\
Alcohol & & \\
Inositol & 1.0 & 0.4 \\
\hline
\end{tabular}

Data are expressed as $\mathrm{mg} / \mathrm{g}$ dry weight of tissue.

compounds found in pine needles included numerous monomeric phenolics and flavonoids (Table 3). Only very small amounts of 2 terpenes were found in the pine needle tissue (Table 3). Qualitatively, condensed tannins were present in large quantities (exceeding detection limits of $10 \%$ ), and alkaloids were absent from pine needles (Table 3).

\section{Trial 1}

Pine needles had no effect on DMI or DDMI; however N intake was depressed by about $18 \%$ by addition of the pine needles (Table 4). Addition of needles also had no effect on fecal N or on DM or ADF digestibility coefficients (Table 4). Needles tended to depress CP digestibility at both the 15 and $30 \%$ levels.

Both FDR and FOR tended to be negatively affected by pine needles (Table 5), with most of this effect attributable to $30 \%$ pine needles. Ruminal volume and TOT were not affected by needles in spite of large differences in mean values (Table 5) because of high variability within the $30 \%$ treatment.

Addition of $30 \%$ pine needles depressed ruminal production of total VFA about $15 \%$ (Table 6). Molar proportions of acetate
Table 3. Plant secondary compounds ( $\mathrm{mg} / \mathrm{g}$ dry weight) in pine needle tissue collected in central Montana.

\begin{tabular}{lcc}
\hline \hline $\begin{array}{l}\text { Class of compound/ } \\
\text { chemical }\end{array}$ & Trial 1 & Trial 2 \\
\hline $\begin{array}{l}\text { Monomeric phenolics } \\
\text { p-hydroxy benzoic acid }\end{array}$ & 0.08 & 0.06 \\
caffeic acid & 0.04 & 0.04 \\
p-coumaric acid & 0.08 & 0.01 \\
ferulic acid & 0.05 & 0.02 \\
gallic acid & 0.60 & 0.38 \\
vanillic acid & 0.05 & 0.01 \\
Flavonoids & & \\
kaempferol & 0.04 & 0.02 \\
naringen & 1.84 & 1.11 \\
quercetin & 0.23 & 0.09 \\
taxifolin & 0.13 & 0.09 \\
Terpenes \\
alpha-pinene & & \\
beta-pinene & 0.01 & 0.002 \\
Tannins & - & Present \\
Alkaloids & Present & Absent \\
\hline
\end{tabular}

"Most of the terpenes typical of ponderosa pine were not present likely because of use of air-dried plant material.

${ }^{b}$ Tannins were not quantified on a $\mathrm{mg} / \mathrm{g}$ basis because the concentration was beyond the limits of the method used (i.e. $>10 \%$ ).

'Alkaloid analysis by Dr. F. Stermitz, Colorado State Univ., pers. comm.

Table 5. Ruminal fluid dilution rate (FDR), rumen volume (VOL), turnover time (TOT), and fluid outflow rate (FOR) in steers during Trial 1.

\begin{tabular}{lrrrrr}
\hline \hline & \multicolumn{3}{c}{ Pine needles, \% } & & \\
\cline { 2 - 4 } Item & \multicolumn{1}{c}{0} & \multicolumn{1}{c}{15} & 30 & MSE $^{\mathrm{a}}$ & Response $^{\mathrm{b}}$ \\
\hline FDR, \%/hour & 8.4 & 8.1 & 5.8 & 1.7 & L, P = 0.06 \\
VOL, hiters & 41.3 & 41.2 & 49.0 & 11.0 & NS \\
TOT, hours & 12.3 & 12.5 & 22.4 & 9.4 & NS \\
FOR, liters/hour & 3.4 & 3.4 & 2.6 & 0.6 & L, P = 0.1 \\
\hline
\end{tabular}

Root mean square error; $n=4$ for all table values.

${ }^{b} \mathbf{L}=$ linear; $\mathbf{N S}=$ nonsignificant at $P>0.10$.

increased linearly, while butyrate decreased; no other VFA were affected by pine needles (Table 6). Ruminal ammonia-N concentrations were depressed by $18 \%$ with the $30 \%$ addition of pine needles (Table 6). Ruminal pH was depressed slightly by $15 \%$ pine needles and elevated by the $30 \%$ treatment (Table 6).

Trial 2

Addition of $40 \%$ pine needles resulted in a $20 \%$ decrease in DMI compared with controls (Table 7). There was no effect of CSM and no pine needle $\times$ CSM interaction. Similarly, DDMI was depressed more than $20 \%$ by pine needles, but no CSM effect or

Table 4. Dry matter (DM) intake, digestible dry matter intake (DDMI), nitrogen (N) intake and fecal N, and digestibility coefficients for DM, crude protein (CP), and acid detergent fiber (ADF) in Trial 1.

\begin{tabular}{|c|c|c|c|c|c|}
\hline \multirow[b]{2}{*}{ Item } & \multicolumn{3}{|c|}{ Pine needles, $\%$} & \multirow[b]{2}{*}{$\mathrm{MSE}^{\mathrm{b}}$} & \multirow[b]{2}{*}{ Response $^{c}$} \\
\hline & 0 & 15 & 30 & & \\
\hline $\begin{array}{l}\text { DM intake, g/day } \\
\text { DDMI, g/day } \\
\mathrm{N} \text { intake, g/day } \\
\text { Fecal N, g/day } \\
\text { DM digestibility, \% } \\
\text { CP digestibility, \% } \\
\text { ADF digestibility, \% }\end{array}$ & \begin{tabular}{r|}
4,372 \\
2,410 \\
54.9 \\
21.8 \\
55.0 \\
59.7 \\
44.7
\end{tabular} & $\begin{array}{r}4,300 \\
2,235 \\
45.6 \\
26.0 \\
51.9 \\
42.9 \\
37.3\end{array}$ & $\begin{array}{r}3,852 \\
2,052 \\
44.6 \\
25.4 \\
53.9 \\
42.4 \\
36.6\end{array}$ & $\begin{array}{r}447 \\
322 \\
5.5 \\
5.2 \\
7.1 \\
12.3 \\
10.4\end{array}$ & $\begin{array}{l}\text { NS } \\
\text { NS } \\
\text { L, } P<0.05 \\
\text { NS } \\
\text { NS } \\
\text { L, } P=0.07 \\
\text { NS }\end{array}$ \\
\hline
\end{tabular}

"Includes pine needles dosed intraruminally at 736 and $1,511 \mathrm{~g} /$ day to 15 and $30 \%$ treatment groups, respectively.

${ }^{b}$ Root mean square error; $n=4$ for all table values.

${ }^{c} \mathrm{~L}=$ linear; $\mathrm{NS}=$ nonsignificant at $P>0.10$ 
Table 6. Ruminal volatile fatty acids (VFA), rumen ammonia N, and ruminal pH in steers fed pine needles in Trial 1.

\begin{tabular}{|c|c|c|c|c|c|}
\hline \multirow[b]{2}{*}{ Item } & \multicolumn{3}{|c|}{ Pine needles, $\%$} & \multirow[b]{2}{*}{ MSE $^{\mathbf{a}}$} & \multirow[b]{2}{*}{ Response $^{b}$} \\
\hline & 0 & 15 & 30 & & \\
\hline Total VFA, mM & 67.1 & 65.2 & 56.0 & 12.1 & $\mathrm{~L}, P<0.01$ \\
\hline Individual VFA & \multicolumn{3}{|c|}{ - - moles/ 100 moles - . } & & \\
\hline Acetate & 69.2 & 70.3 & 70.2 & 1.9 & L, $P<0.05$ \\
\hline Propionate & 18.6 & 18.0 & 18.3 & 1.4 & NS \\
\hline Butyrate & 8.7 & 8.4 & 7.6 & 0.8 & $\mathrm{~L}, P<0.01$ \\
\hline Isobutyrate & 1.4 & 1.3 & 1.7 & 0.8 & NS \\
\hline Valerate & 1.1 & 1.2 & 1.1 & 0.4 & NS \\
\hline Isovalerate & 0.9 & 0.8 & 1.0 & 0.4 & NS \\
\hline \multicolumn{6}{|l|}{ Rumen ammonia-N, } \\
\hline $\mathrm{mg} / \mathrm{dl}$ & 4.4 & 4.3 & 3.6 & 1.3 & $\mathrm{~L}, P<0.05$ \\
\hline Ruminal pH & 6.7 & 6.7 & 6.9 & 0.2 & $Q, P<0.01$ \\
\hline
\end{tabular}

${ }^{2}$ Root mean square error; $\mathrm{n}=32$ for all table values.

${ }^{b} \mathrm{~L}=$ linear; $\mathrm{Q}=$ quadratic; $\mathrm{NS}=$ nonsignificant at $P>0.10$.

interaction was noted (Table 7). As expected, $\mathrm{N}$ intake was increased by the addition of CSM, but addition of pine needles decreased $\mathrm{N}$ intake by $32 \%$. Fecal $\mathrm{N}$ levels (g/day) increased $(P=0.08)$ with addition of pine needles, but fecal $N$ was not affected by addition of CSM, and no CSM $\times$ pine needle interaction was detected (Table 7).
Dry matter digestibility was reduced about $10 \%$ by pine needles; CSM or CSM $\times$ pine needle interaction effects were not apparent (Table 7). Apparent crude protein digestibility was depressed severely by pine needles, with a reduction to $24 \%$ in the pine needle treatment compared with $59 \%$ in controls. Again, no CSM effect or CSM $\times$ pine needle interaction was noted.

Ruminal fluid kinetics were altered by pine needles. Fluid dilution rate was reduced by $40 \%$ by pine needles, and no CSM effect or interaction was found (Table 8). Turnover time was markedly elevated from about 14 hours in controls to 28 hours in cattle fed pine needles; no CSM effect or interaction was noted. Fluid outflow rate also was depressed by $40 \%$ from pine needles, with no effect from the addition of CSM, and no CSM $\times$ pine needle interaction (Table 8).

Pine needles increased total VFA concentration, but CSM had no effect and there was no interaction (Table 9). Proportions of individual VFA were not affected by pine needles or CSM, nor were there any interactions. Ruminal ammonia- $\mathrm{N}$ was depressed by pine needles, but no CSM effect or interaction was found (Table 9). Ruminal $\mathrm{pH}$ was elevated by pine needles, but neither CSM nor the CSM $\times$ pine needle interaction were significant (Table 9).

\section{Discussion}

Pine needles contained numerous secondary compounds in

Table 7. Dry matter intake ( $\mathrm{g} /$ day), $\mathrm{N}$ intake and fecal $\mathrm{N}$, digestible dry matter intake (DDMI), and digestion coefficients for DM, crude protein (CP) and acid detergent fiber (ADF) in steers fed pine needles in Trial 2.

\begin{tabular}{|c|c|c|c|c|c|c|}
\hline \multirow[b]{2}{*}{ Item } & \multicolumn{4}{|c|}{ Treatments } & \multirow[b]{2}{*}{$\mathrm{MSE}^{\mathrm{b}}$} & \multirow[b]{2}{*}{ Response $^{c}$} \\
\hline & CONT & CSM & PN & CSMPN & & \\
\hline DM intake, $g /$ day & 6,801 & 7,204 & 5,363 & 5,908 & 1,127 & $\begin{array}{l}\text { PN: } P=0.05 \\
\text { CSM: NS }\end{array}$ \\
\hline$N$ intake, $g /$ day & 100.9 & 135.0 & 68.6 & 101.5 & 20.2 & $\begin{array}{c}\text { PN: } P<0.05 \\
\text { CSM: } P<0.05\end{array}$ \\
\hline Fecal N, g/day & 41.2 & 46.2 & 49.4 & 60.6 & 10.8 & $\begin{array}{l}\text { PN: } P=0.08 \\
\text { CSM: NS }\end{array}$ \\
\hline DDMI, g/day & 4,281 & 4,652 & 3,098 & 3,293 & 754 & $\begin{array}{l}\text { PN: } P<0.05 \\
\text { CSM: NS }\end{array}$ \\
\hline \multicolumn{7}{|c|}{ Digestion coefficients } \\
\hline $\mathrm{DM}$ & 63.1 & 64.7 & 57.3 & 53.5 & 4.1 & $\begin{array}{l}\text { PN } P<0.05 \\
\text { CSM: NS }\end{array}$ \\
\hline ADF & 55.0 & 61.3 & 41.7 & 34.5 & 5.7 & $\begin{array}{l}\text { PN: } P<0.05 \\
\text { CSM: NS }\end{array}$ \\
\hline CP & 59.1 & 65.8 & 23.9 & 36.2 & 10.4 & $\begin{array}{l}\text { PN: } P<0.05 \\
\text { CSM: NS }\end{array}$ \\
\hline
\end{tabular}

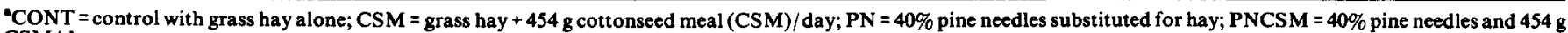
CSM/day.

${ }^{b}$ Root mean square error; $n=$ for all table values.

${ }^{\circ} \mathrm{PN}=$ Pine needle effect $; \mathrm{CSM}=\mathrm{CSM}$ effect $; \mathrm{NS}=$ nonsignificant at $P>0.10$. There were no $\mathrm{PN} \times \mathrm{CSM}$ interaction.

Table 8. Ruminal fluid dilution rate (FDR), rumen volume (VOL), turnover time (TOT), and fluid outllow rate (FOR) in steers given pine needles and cottonseed meal in Trial 2.

\begin{tabular}{|c|c|c|c|c|c|c|}
\hline \multirow[b]{2}{*}{ Item } & \multicolumn{4}{|c|}{ Treatments $^{\mathrm{a}}$} & \multirow[b]{2}{*}{$\mathrm{MSE}^{\mathrm{b}}$} & \multirow[b]{2}{*}{ Response $^{c}$} \\
\hline & CONT & CSM & PN & CSMPN & & \\
\hline FDR, \%/hour & 6.9 & 7.1 & 4.0 & 5.9 & 0.9 & $\begin{array}{l}\text { PN: } P<0.01 \\
\text { CSM: NS }\end{array}$ \\
\hline VOL, liters & 102.9 & 94.6 & 111.1 & 90.7 & 13.1 & All NS \\
\hline TOT, hours & 14.2 & 14.7 & 27.7 & 17.1 & 4.7 & $\begin{array}{l}\text { PN: } P<0.05 \\
\text { CSM: NS }\end{array}$ \\
\hline FOR, liters/hour & 7.2 & 6.5 & 4.3 & 5.2 & 0.9 & $\begin{array}{l}\text { PN: } P<0.01 \\
\text { CSM: NS }\end{array}$ \\
\hline
\end{tabular}

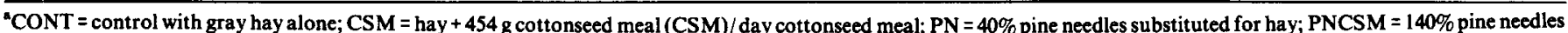
and 454 g CSM/day.

${ }^{6} \mathrm{Root}$ mean square error; $\mathrm{n}=$ for all table values.

'PN = PN effect; CSM = CSM effect; NS = nonsignificant at $P>0.10$. 
Table 9. Ruminal volatile fatty acids (VFA), rumen ammonia-N and ruminal pH in steers fed cottonseed meal and pine needles in Trial 2.

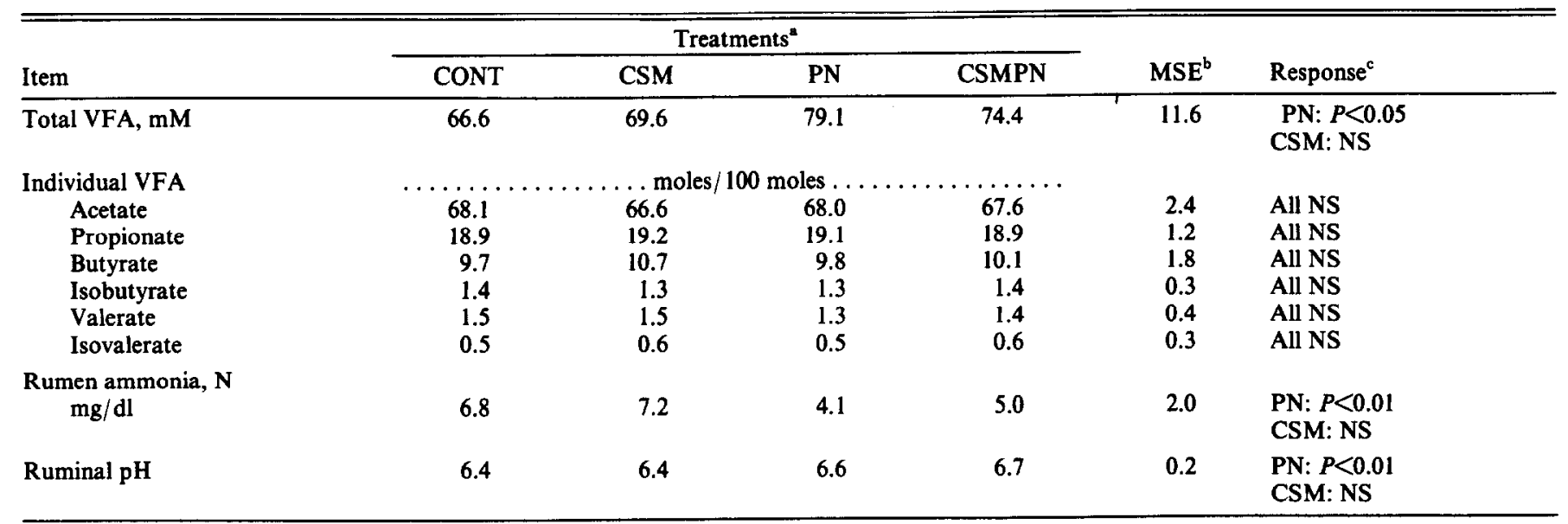

${ }^{\mathrm{a}} \mathrm{CONT}=$ control with grass hay alone; $\mathrm{CSM}=$ grass hay $+454 \mathrm{~g}$ cottonseed meal $(\mathrm{CSM}) /$ day; $\mathrm{PN}=40 \%$ pine needles substituted for hay; $\mathrm{PNCSM}=40 \%$ pine needles and $454 \mathrm{~g}$ $\operatorname{CSM} /$ day.

${ }^{6}$ Root mean square error; $\mathrm{n}=20$ for VFA and $\mathrm{pH} ; \mathrm{n}=16$ for $\mathrm{NH}_{3}$.

${ }^{\circ} \mathrm{PN}=\mathrm{PN}$ effect; $\mathrm{CSM}=\mathrm{CSM}$ effect; NS = nonsignificant at $P>0.10$

small amounts. The percentage of tannins was substantial (i.e., $>10 \%$ ), which agrees with findings of Wagner and Evans (1985) for ponderosa pine, and Watt (1989) for Pinus contorta Douglas and Pinus sylvestris L. Contrary to other results (Hanover 1966, Smith 1964), concentrations of monoterpenes were very low, which was probably a result of air-drying the needles before analysis. Regardless, the abortifacient compound(s) was probably not affected, as both fresh and dried needles abort pregnant cattle (Short et al. 1989). Our experiment was not designed to test whether the abortive agent also is responsible for the nutritional toxicology.

Dry matter intake was not affected in Trial 1 , but was reduced by pine needles in Trial 2. We caution that animals were not allowed to orally consume pine needles; we gave pine needles intraruminally to remove any palatability effects. Adams et al. (1992) found that intake was affected by addition of $50 \%$ pine needles to sheep diets.

Nitrogen intake was reduced by pine needles in both trials, but elevated by CSM in Trial 2. Most differences can be attributed to greater $\mathrm{N}$ content in hay and CSM compared with needles. As shown in numerous other studies where browse was fed (Quercus spp.: Nastis and Malechek 1981, Villena and Pfister 1990; Cercocarpus and Atriplex spp.: Boutouba et al. 1990; Artemisia and Juniperus spp.: Nunez-Hernandez et al. 1989), fecal N was elevated about $15 \%$ in both trials by addition of pine needles. No increase in fecal $\mathbf{N}$ resulted from feeding CSM because of its high digestibility.

The 2 trials were not entirely consistent with respect to effects of needles on digestion coefficients. In Trial 1 , needles negatively affected ( $P=0.07$ ) CP digestibility; pine needles affected all digestion coefficients in Trial 2. Cottonseed meal did not effect DM digestion coefficients in Trial 2. We consistently found no CSM $\times$ pine needle interaction for any variable. The literature is replete with examples of high-phenolic feeds adversely affecting digestion (tannins: Bernays et al. 1989; phenolic compounds in grass and browse: Jung 1985, Palo 1985, Palo et al. 1985, Hartley and Akin 1989). In 2 companion studies, we found: (1) that pine needles reduce the in vivo and in vitro digestibility of grass hay (Adams et al. 1992), and (2) that needles are especially toxic to cellulolytic bacteria (Wiedmeier et al. 1992), but also reduce proteolytic bacterial populations and total numbers of bacteria and protozoa.

Ruminal fluid measurements indicated significant impacts on fluid dilution and outflow rates in both trials. Fluid dilution rate was reduced in Trial 1 by $30 \%$ pine needles even though DMI was not affected. Both FDR and DMI were reduced in Trial 2. Reduc- tions in DMI have been shown to reduce FDR in cattle on low quality roughages (Adams and Karchner 1984). Salivary flow has been reported to increase at higher levels of forage intake (Bartley 1975), and increased salivary flow may enhance FDR (Harrison et al. 1975). Because we dosed pine needles to cattle rather than allowing oral consumption, actual oral DMI was much lower for pine-fed cattle, and salivary flow may have been reduced, with consequent impacts on FDR. Toxic compounds may also reduce ruminal motility (Aungst and Shen 1986), thus reducing rate of passage.

Effects on TOT were not significant in Trial 1, even though the mean TOT for the $30 \%$ group was nearly double the control value. Of the 4 animals on this treatment, 2 were severely affected, and 2 were noticably unaffected by needles, thus individual animal variability prevented the detection of significant differences. One animal from the 30PN group eventually went off feed and developed a bloody rectal discharge. Veterinary examination indicated damage to the gastrointestinal tract from the pine needles. Bailey (1978) noted that high phenolic diets can cause bloody feces due to necrosis of the gastrointestinal tract.

Ruminal fluid volume was unaffected by pine needles in both trials. Although fluid volumes were high in Trial 2, these values are comparable to values reported in other studies with low forage intake and low quality roughage (Adams and Karchner 1984).

Total VFA were reduced by pine needles in Trial 1, but paradoxically were increased in Trial 2; we have no adequate explanation for these results. Pine needles affected only proportions of acetate and butyrate in Trial 1, but not in Trial 2. We know that ruminal microbial populations were changing over time in both trials (Wiedemeier et al. 1992); more detailed study will be required to clarify the dynamic process by which pine needles affect VFA concentrations.

Ruminal ammonia- $\mathrm{N}$ concentrations were depressed in both trials as a result of pine needles. In both trials, ammonia- $N$ concentrations in needle-fed animals fell below levels generally considered necessary for adequate ruminal fermentation (Van Soest 1982). Peterson (1987) recently suggested that recommended levels of ammonia-N may be much lower for grazing livestock. Ruminal pH was increased from feeding pine needles in both trials, perhaps because of effects of secondary compounds on fermentation, or because of lower forage intake relative to salivary flow.

Both trials showed conclusively that pine needles have an adverse effect on cattle nutrition, confirming and extending find- 
ings from other studies we have conducted (Adams et al. 1992, Wiedmeier et al. 1992). Trial 1 was the first in vivo study of pine needle effects in cattle, and some results differ from those with lambs consuming pine needles (Adams et al. 1992). Minor differences aside, all the research that we have conducted indicates substantial detrimental effects in sheep and cattle ingesting pine needles. Pine needles primarily reduce feed intake, bind nitrogen, and directly or indirectly alter passage rate and fermentation. Separating the effects of reduced intake alone from other pine needle effects will require pair-feeding to eliminate confounding effects.

Supplementation of diets with CSM did not ameliorate any adverse effects of pine needles. Producers with cattle consuming pine needles during winter should consider the nutritional implications that these adverse effects may impose on cattle, especially in terms of feed intake, weight losses, and postpartum intervals. However, in our opinion, the primary impact of pine needle ingestion is probably not nutritional, even though nutritional effects are real and potentially severe. Abortions in cattle consuming pine needles can decimate herd productivity, and greatly increase calving interval in recovering cows (James et al. 1989); thus, economic impacts can be devastating (Lacey et al. 1988).

\section{Literature Cited}

Adams, D.C. and R.J. Kartchner. 1984. Effect of level of forage intake on rumen ammonia, $\mathrm{pH}$, liquid volume and liquid dilution rate in beef cattle. J. Anim. Sci. 58:708-713.

Adams, D.C., J.A. Pfister, R.E. Short, R.G. Cates, R.D. Wiedmeier, and B.N. Knapp. 1992. Pine needle effects on in vivo and in vitro digestibility of crested wheatgrass. J. Range Manage. 45:249-253.

AOAC. 1984. Official methods of analysis (14th ed.). Association of Official Analytical Chemists. Washington, D.C.

Akin, D.E. 1982. Forage cell wall degradation and p-coumaric, ferulic and sinapic acids. Agron. J. 74:424-428.

Akin, D.E. 1989. Histological and physical factors affecting digestibility of forages. Agron. J. 81:17-25.

Aungst, B., and D.D. Shen. 1986. Gastrointestinal absorption of toxic agents. p. 29-52. In: K. Rozman and O. Hanninen (eds.) Gastrointestinal toxicology. Elsevier, N.Y.

Bailey, E.M. 1978. Physiologic response of livestock to toxic plants. J. Range Manage. 31:343-346.

Bartley, E.E. 1975. Bovine saliva: Production and function. p. 61-77. In: M.S. Weinburg and A.L. Sheffner (eds.) Buffers in ruminant physiology and metabolism, Church and Dwight Co., Inc., N.Y.

Bernays, E.A., G. C. Driver, and M. Bilgener. 1989. Herbivores and plant tannins. p. 263-301. In: Advances in ecological research, Vol. 19, Academic Press, N.Y.

Boutouba, A., J.L. Holechek, M.L. Galyean, G. Nunez-Hernandez, J.D. Wallace, and M. Cardenas. 1990. Influence of two native shrubs on goat nitrogen status. J. Range Manage. 43:530-534.

Chesson, A., C.S. Stewart, and R.J. Wallace. 1982. Influence of plant phenolic acids on growth and cellulolytic activity of rumen bacteria. Appl. Environ. Microbiol. 44:597-603.

Gartner, F.R., F.D. Johnson, and P. Morgan. 1988. Cattle abortion from ponderosa pine needles: ecological and range management considerations. p. 71-93. In: L.F. James, M.H. Ralphs, and D.B. Nielsen (eds.). The ecology and economic impact of poisonous plants on livestock production. Westview Press, Boulder, Colo.

Goering, H.K., and P.J. Van Soest. 1970. Forage fiber analyses. USDAARS Agr. Handb. 379.
Hanover, J.W. 1966. Environmental variation in the monoterpenes of Pinus monticola Dougl. Phytochemistry 5:713-717.

Harrison, D.G., D.E. Beever, D.J. Thompson, and D.F. Osborn. 1975. Manipulation of rumen fermentation in sheep by increasing the rate of flow of water from the rumen. J. Agr. Sci. (Camb.) 85:93-101.

Hartley, R.D., and D.E. Akin. 1989. Effect of forage cell wall phenolic acids and derivatives on rumen microflora. J. Sci. Food Agr. 49:405-410.

Horner, J., R.G. Cates, and J. Gosz. 1987. Tannin, nitrogen, and cell wall composition of green vs. senescent Douglas-fir foliage: within and between stand differences in stands of unequal density. Oecologia 72:515-519.

James, L.F., R.E. Short, K.E. Panter, R.J. Molyneux, L.D. Stuart, and R.A. Bellows. 1989. Pine needle abortion in cattle: a review and report of 1973-1984 research. Cornell Vet. 79:39-52.

Jung, H.G. 1985. Inhibition of structural carbohydrate fermentation by forage phenolics. J. Sci. Food Agr. 36:74-80.

Kumar, R., and M. Singh. 1984. Tannins: their adverse role in ruminant nutrition. J. Agr. Food Chem. 32:447-453.

Lacey, J.R., L.F. James, and R.E. Short. 1988. Ponderosa pine: economic impact. p. 95-106. In: L.F. James, M.H. Ralphs, and D.B. Nielsen (eds.). The ecology and economic impact of poisonous plants on livestock production. Westview Press, Boulder, Colo.

Nastis, A.S., and J.C. Malechek. 1981. Digestion and utilization of nutrients in oak browse by goats. J. Anim. Sci. 53:283-289.

Nunez-Hernandez, G., J.L. Holechek, J.D. Wallace, M.L. Galyean, A. Tembo, R. Valdez, and M. Cardenas. 1989. Influence of native shrubs on nutritional status of goats: nitrogen retention. J. Range Manage. 42:228-232.

Palo, R.T. 1985. Chemical defense in birch: inhibition of digestibility in ruminants by phenolic extracts. Oecologia 68:10-14.

Palo, R.T., K. Sunnerheim, and O. Theander. 1985. Seasonal variation of phenols, crude protein and cell wall content of birch (Betula pendula Roth.) in relation to ruminant in vitro digestibility. Oecologia 65:314-318.

Peterson, M.K. 1987. Nitrogen supplementation of grazing livestock. p. 115-121. In: Proc. Grazing Livestock Nutrition Conf., Univ. Wyoming, Laramie.

Pfister, J.A., and D.C. Adams. 1992. Consumption of toxic pine needles by free-grazing cows during winter in Montana. J. Range Manage. (in review).

SAS. 1987. SAS/STAT for Personal Computers. 6th Ed., SAS Inst., Cary, N.C.

Short, R.E., R.B. Staigmiller, D.C. Adams, R.A. Bellows, K.E. Panter, J.A. Pfister, and L.F. James. 1989. Effects of feeding pine needles to cattle: abortion response and physiological mechanisms. Proc. The Range Beef Cow Symposium XI, South Dakota State Univ., Rapid City.

Smith, R.N. 1964. Variation in the monoterpenes of Pinus ponderosa Laws. Science 143:1337-1338.

Tagari, H., Y. Henis, M. Tamir, and R. Volcani. 1965. Effect of carob pod extract on cellulolysis, proteolysis, deamination and protein biosynthesis in an artificial rumen. Appl. Microbiol. 13:437-443.

Uden, P., P.E. Colucci, and P.J. Van Soest. 1980. Investigation of chromium, cericum, and cobalt as markers in digesta rate of passage studies. J. Sci. Food Agr. 31:625-631.

Van Soest, P.J. 1982. Nutritional ecology of the ruminant. O \& B Books, Corvallis, Ore.

Villena, F., and J.A. Pfister. 1990. Sand shinnery oak as forage for Angora and Spanish goats. J. Range Manage. 43:116-122.

Wagner, M.R., and P.D. Evans. 1985. Defoliation increases nutritional quality and allelochemic of pine seedlings. Oecologia 67:235-237.

Watt, A.D. 1989. The chemical composition of pine foliage in relation to the population dynamics of the pine beauty moth, Panolis flammea, in Scotland. Oecologia 78:251-258.

Wiedmeier, R.D., J.A. Pfister, D.C. Adams, and R.G. Cates. 1992. Toxicity of pine needles to ruminal microbial populations. Appl. Environ. Microbiol. (in review). 